\title{
Osthole Induces Cell Cycle Arrest and Inhibits Migration and Invasion via PTEN/ Akt Pathways in Osteosarcoma
}

\author{
Lu Wang $^{\mathrm{a}}$ Lei Yang ${ }^{\mathrm{b}}$ Ying Lu ${ }^{\mathrm{a}}$ Yingzhun Chen ${ }^{\mathrm{C}}$ Tianhua Liu ${ }^{\mathrm{a}}$ Yanli Peng ${ }^{\mathrm{a}}$ \\ Yuhong Zhou ${ }^{a}$ Yang Cao ${ }^{b}$ Zhenggang Bi ${ }^{b}$ Tianyi Liu ${ }^{a}$ Zhenhong Liu ${ }^{a}$ \\ Hongli Shan ${ }^{\mathrm{a}}$
}

\begin{abstract}
aDepartment of Pharmacology (State-Province Key Laboratories of Biomedicine- Pharmaceutics of China, Key Laboratory of Cardiovascular Research, Ministry of Education), Harbin Medical University, Harbin, 'Department of Orthopedics, the First Affiliated Hospital of Harbin Medical University, Harbin, 'Department of Pathology, the 2nd Affiliated Hospital, Harbin Medical University, Harbin, P. R. China
\end{abstract}

\section{Key Words}

Osthole $\cdot$ Cell cycle $\cdot$ Migration and invasion • Osteosarcoma • PTEN/Akt • Tumor suppressor

\begin{abstract}
Background/Aims: Osteosarcoma is the second highest cause of cancer-related death in children and adolescents. Majority of osteosarcoma patients (90\%) show metastasis. Previous reports revealed that osthole showed antitumor activities via induction of apoptosis and inhibition of proliferation. However, the potential effects and detailed molecular mechanisms involved remained unclear. Methods: Cell viability was analyzed by MTT assay in osteosarcoma cell lines MG-63 and SAOS-2. Cell cycle was detected by flow cytometry. The effects of migration and invasion were evaluated by wound healing assay and transwell assays. Moreover, the level of proteins expression was determined by Western blot. Results: The cell viability of MG63 and SAOS-2 were markedly inhibited by osthole in a dose- and time-dependent manner. Cell cycle was arrested and the ability of migration and invasion was obviously reduced when cells were exposed to osthole. Moreover, enzymes involved in PTEN/ Akt pathway were regulated such as PTEN and p-Akt proteins. Furthermore, osthole inhibited the tumor growth in vivo. Conclusion: Our study unraveled, for the first time, the ability of osthole to suppress osteosarcoma and elucidated the regulation of PTEN/Akt pathway as a signaling mechanism for the anti-tumor action of osthole. These findings indicate that osthole may represent a novel therapeutic strategy in the treatment of osteosarcoma.

\section{Introduction}

Osteosarcoma is the most common form of primary malignant bone cancer which is most prevalent in children and adolescents. Systematic chemotherapy is the first choice of L. Wang and L. Yang contributed equally to this study.

Dr. Hongli Shan

KARGER
Department of Pharmacology, Harbin Medical University, Baojian Road 157, Harbin 150086, Heilongjiang Province, (P.R.China)

Tel. 86-451-86671354, Fax 86-451-86671354, E-Mail shanhongli@ems.hrbmu.edu.cn 


\section{Cellular Physiology Cell Physiol Biochem 2016;38:2173-2182 and Biochemistry Published online: May 17, $2016 \quad$\begin{tabular}{l|l} 
DOI: 10.1159/00445573 2016 The Author(s). Published by S. Karger AG, Basel \\
www.karger.com/cpb
\end{tabular} \\ Wang et al.: Osthole Inhibits Osteosarcoma}

treatment. However, the survival rate for osteosarcomas is only $50 \%$ to $80 \%$ despite with an intensive chemotherapy. Numerous efforts have been made to elucidate the mechanisms of osteosarcoma and to develop novel therapeutic strategies [1, 2]. Cell growth and division cycle were carefully controlled in normal tissues, thereby ensuring a homeostasis of cell number and thus maintenance of normal tissue architecture and function. Loss of normal cell cycle control is a hallmark of human cancers [3]. Many researches had focused on the fundamentally distinct anti-tumor strategies targeting the cell cycle, mainly blocking cell cycle progression. As approximately $90 \%$ of patients who suffered from osteosarcoma show metastasis at the time of initial diagnosis, many studies have focused on the molecular and/ or cellular mechanisms underlying tumor formation and progression $[4,5]$. It was obvious that local invasion and distant migration are considered to be higher degree of malignancy in osteosarcoma. Altough long-term survival probabilities for osteosarcoma have improved dramatically during the late 20th century; systemic chemotherapy has been shown to be ineffective and nearly $20 \%$ if death resulted from lung metastasis. Therefore, there is a marked requirement to develop effective therapeutic strategies that suppress metastasis, the major cause of death in osteosarcoma.

Accumulating evidence suggests that natural agents could open new avenues for the successful treatment of cancers, especially by combining with conventional therapeutics [6]. Natural agents have been and continued to be important sources of anticancer agents. Such as, allicin suppresses pancreatic cancer cell via apoptotic pathway, and curcumin plays a crucial role in anti-lung cancer activity. Moreover, it is reported that formononetin plays an important function on anti-cancer activity against osteosarcoma [7-9]. Osthole is one of effective monomers found in Cnidium monnieri. Its chemical formula is $\mathrm{C}_{15} \mathrm{H}_{16} \mathrm{O}_{3^{*}}$. Osthole has been shown to exert a wide variety of biological effects, such as anti-seizure, anti-osteoporosis and anti-inflammation [10-13]. It has been well documented that osthole inhibits the growth and proliferation of various cancer cells through inducing apoptosis or cell cycle arrest [14, 15]. Moreover, osthole derivative NBM-T-BMX-OS01 sensitizes A549 cells to cisplatin [16]. However, little is known regarding to the underlying mechanisms of therapeutic effects of osthole and there were no reports that osthole regulates cell cycle, migration, and invasion in osteosarcoma treatment.

PTEN (phosphatase and tensin homolog, deleted on chromosome ten) is a dual lipid and protein phosphatase that can dephosphorylate its downstream targets. Inactivation of PTEN leads to loss of its lipid phosphatase activity and accumulation of phosphatidylinositol 3, 4, 5-trisphosphate (PIP3), resulting in phosphorylation of Akt. PI3k/Akt and PTEN are major positive and negative regulators respectively in tumorigenesis. The regulation of PI3k/Akt pathway in proliferation, growth, and survival provides irrefragable evidence of the central role of this pathway in tumorigenesis [17]. Similarly, a plethora of cellular processes such as proliferation, survival, and energy metabolism are governed by the tumor-suppressor genes PTEN [18]. As a result, inactivation of PTEN stimulates cell cycle progression and proliferation by down-regulating p21/WAF1/CIP1. On the other hand, it prevents cancer cells from apoptosis by inhibiting apoptotic pathways $[19,20]$. It is not known, however, whether the anti-cancer effects of osthole are related to this pathway.

In view of the established anti-tumor effects of osthole and the tumorigenic role of the PTEN/Akt pathway in osteosarcoma, we proposed that osthole may regulate osteosarcoma growth, cell cycle, migration, and invasion via the PTEN/Akt pathway. This study was designed to test this hypothesis.

\section{Materials and Methods}

\section{Materials}

Osthole (> 98\%) was purchased from Nanjing Ze Lang Pharmaceutical Technology Co., LTD, China. Cisplatin was bought from Qilu Pharmacy Co., LTD, China. 


\section{Cellular Physiology Cell Physiol Biochem 2016;38:2173-2182 and Biochemistry Published online: May 17, $2016 \quad \begin{aligned} & \text { DOI: 10.1159/000445573 } 2016 \text { The Author(s). Published by S. Karger AG, Basel } \\ & \text { www.karger.com/cpb }\end{aligned}$ \\ Wang et al.: Osthole Inhibits Osteosarcoma}

Cell culture

The human osteosarcoma cell lines, MG-63 and SAOS-2, were purchased from National Platform of Experimental Cell Resources for Sci-Tech (Beijing, China). MG-63 cells were cultured in MEM-EBSS (Hyclone, USA) supplemented with 10\% FBS, whereas SAOS-2 cells were cultured in McCoy's $5 \alpha$ Medium supplemented with $15 \% \mathrm{FBS}$, in the presence of $100 \mathrm{mg} / \mathrm{ml}$ penicillin/streptomycin and $5 \% \mathrm{CO}_{2}$ at $37^{\circ} \mathrm{C}$.

\section{Cell Viability Assays}

The cells were cultured in 96-well plates, and each well was seeded with $4 \times 10^{3}$ cells. After treatment with osthole and negative control for 12,24 , and 48 hours, the viability of the cancer cells was detected with 3-(4, 5-dimethylthiazol-2-yl)-2, 5-diphenyl tetrazolium bromide (MTT; Roche; Switzerland). $20 \mu \mathrm{l}$ of MTT solution $(5 \mathrm{mg} / \mathrm{ml})$ was added to each well, and the mixtures were incubated for $4 \mathrm{~h}$ at $37^{\circ} \mathrm{C}$. Then, $150 \mu \mathrm{l}$ of dimethyl sulfoxide (DMSO) was added to the wells. The absorbance was measured using an ELISA plate reader at $490 \mathrm{~nm}$. A high absorbance indicated a greater viability.

\section{Cell cycle analysis by flow cytometry}

After starvation for $12 \mathrm{~h}, \mathrm{MG}-63$ and SAOS-2 cells were treated with osthole at 0, 50, 100, and $150 \mu \mathrm{M}$ for $24 \mathrm{~h}$. After cells were incubated with RNase (Sigma, USA) and PI (Sigma, USA) [21], the DNA content was evaluated on a FACSCalibur system (BD Biosciences, San Jose, CA, USA) by using ModFitLT V3.2.1. To provide valid quantitative data, $10^{4}$ individual cells were analyzed in each experiment.

\section{Wound healing assay}

Cells were seeded in six-well plates in culture medium. Cells were grown to $70 \%$ confluence, rinsed with phosphate-buffered saline (PBS), and then starved for 12 hours in serum-free medium. A sterile $200 \mu \mathrm{L}$ pipette tip was used to create wounds. Furthermore, $0,50,100$, and $150 \mu \mathrm{M}$ osthole was added respectively. The migration of the cells across the wound line was assessed after 24 hours.

In Vitro Cell Invasion Assay

Cellular invasiveness was quantified using a modified Matrigel Boyden chamber assay, as previous described [22].

\section{Western blot}

The Western blot analysis was conducted as described elsewhere [23]. The total protein was extracted from the cells samples using lysis buffer (Beyotime, China) and protease inhibitor (Biocolors, China). Lysis buffer and protease inhibitor were used after mixed in proportion of 1:100. Equal amounts of protein were loaded on a $10 \%$ SDS-PAGE gel. The lysates were resolved by electrophoresis (70V for 30 min and 100V for $1.5 \mathrm{~h}$ ) and transferred onto NC membranes (nitrocellulose membrane, Bio-Rad, USA). After blocking in $5 \%$ nonfat milk for $2 \mathrm{~h}$ at room temperature, the membranes were incubated with anti-p-Akt (1:1000, Cell Signaling Technology, USA), anti-MMP9 (1:200, Santa, USA), anti-MMP2 (1:200, Santa, USA), anti-p21 (1:200, Santa, USA), anti-PTEN(1:1000, Cell Signaling Technology, USA). GAPDH (glyceraldehyde-3-phosphate) was used as an internal control to ensure equal protein loading. The Western blot bands were quantified using the Odyssey v1.2 software (Infrared Imaging System LI-COR Biosciences) by measuring the band intensity (Area $\times$ OD, Optical Density) for each group and normalizing this intensity by that of GAPDH. The final results are expressed as fold changes by normalizing the data to the control values.

\section{Tumorigenicity assays in nude mice}

$5 \times 10^{6}$ MG-63 cell suspension was subcutaneously injected into the flank of 5-week-old female athymic BALB/c nude mice (Shanghai SLAC Laboratory Animal Company). At 10 days after the implantation, they were treated with $122 \mathrm{mg} / \mathrm{kg}(0.5 \mathrm{mmol} / \mathrm{kg}$ ) osthole intraperitoneally (i.p.) in $0.2 \mathrm{ml}$ corn oil, with corn oil alone as the control group and cisplatin as the positive control once every other day for 2 weeks. The tumor volume was measured with a caliper once every 3 days using the following formula: volume = length $\times$ width $^{2} / 2$. Growth rates were determined by measuring tumor size over time. All animal procedures were approved by the Harbin Medical University Animal Committee.

Statistical analysis

All the data are presented as means \pm SEM. The statistical comparisons among multiple groups were performed using analysis of variance (ANOVA). If significant effects were indicated by ANOVA, a t-test 
using the Bonferroni correction or a Dunnett's test were used to evaluate the significance of the differences between the individual means. Otherwise, the data were compared by Student's t-test. A two-tailed difference with $\mathrm{p}<0.05$ was considered statistically significant. The data were analyzed using GraphPad Prism 5.0 and SPSS 14.0 .

\section{Results}

Osthole inhibits the growth of osteosarcoma cells

The growth of osteosarcoma cell line MG-63 and SAOS-2 were inhibited, as determined by MTT assay, after cells were treated with osthole at $0,25,50,100,150$ and $200 \mu \mathrm{M}$ for 12 h, $24 \mathrm{~h}$, and $48 \mathrm{~h}$, respectively. It was found that osthole inhibited the growth of MG-63 and SAOS- 2 cells in a concentration- and time-dependent manner. Osthole inhibited the growth of MG-63 with an $\mathrm{IC}_{50}$ of $113 \mu \mathrm{M}(24 \mathrm{~h})$ and $109 \mu \mathrm{M}(48 \mathrm{~h})$, and SAOS-2 with an IC $\mathrm{I}_{50}$ of $95 \mu \mathrm{M}$ $(24 \mathrm{~h})$ and $90 \mu \mathrm{M}(48 \mathrm{~h})$. Because the dosages of IC50 (48 h) is not much lower than $\mathrm{IC}_{50}(24$ h), so we only choose $24 \mathrm{~h}$ for latter tests (Fig. 1).

Osthole induces cell cycle arrest at $G_{1} / S$ phase in osteosarcoma cells

Effects of osthole on cell cycle distribution were analyzed by flow cytometry in MG-63 and SAOS- 2 cells. The MG-63 cells were found $54.29 \pm 3.94 \%$ in $\mathrm{G}_{1}$ phase, $39.75 \pm 2.50 \%$ in $\mathrm{S}$ phase and $6.81 \pm 2.85 \%$ in $\mathrm{G}_{2}$ phase under control conditions. After being treated with osthole at 50,100 , or $150 \mu \mathrm{M}$ for $24 \mathrm{~h}$, the number of cells in $\mathrm{G}_{1}$ phase was increased from $59.44 \pm 3.64 \%$ to $73.42 \pm 1.38 \%(\mathrm{P}<0.05)$, whereas that in $\mathrm{S}$ phase was decreased from 39.75 $\pm 2.50 \%$ to $22.99 \pm 1.29 \%$ (P < 0.001). Moreover, The SAOS-2 cells were found $51.07 \pm 1.61 \%$ in $G_{1}$ phase and $40.32 \pm 3.43 \%$ in $S$ phase under control conditions. After being treated with osthole at 50, 100 or $150 \mu \mathrm{M}$ for $24 \mathrm{~h}$, the number of cells in $\mathrm{G}_{1}$ phase was increased from $56.45 \pm 1.32 \%$ to $75.77 \pm 2.27 \%(\mathrm{P}<0.001)$, whereas that in $\mathrm{S}$ phase was decreased from $33.56 \pm 2.38 \%$ to $18.66 \pm 1.27 \%(\mathrm{P}<0.05)$ (Fig. $2 \mathrm{~A})$.

Present results showed that osthole arrested osteosarcoma cell cycle. To determine whether the key inhibitor of cell cycle p21 was regulated by osthole, western blots assays were performed in MG-63 and SAOS-2 cells treated with or without osthole. Our results showed that the level of p21 was up-regulated in osteosarcoma cells after incubating with 50, 100 and $150 \mu \mathrm{M}$ osthole for $24 \mathrm{~h}$ (Fig. 2B).

\section{Osthole inhibits osteosarcoma migration and invasion}

We sought to validate the role of osthole in the migration and invasion of MG-63 and SAOS-2 cells. Wound healing assay was performed firstly. In vitro wound healing assays showed that osthole is an inhibitor of migration of MG-63 and SAOS- 2 cells into the wounded area (Fig. 3A). Furthermore, using in vitro transwell migration assays, we found that osthole inhibits the migration of MG-63 and SAOS-2 cells (Fig. 3B). Moreover, we have also examined

Fig. 1. Osthole regulates the viability of osteosarcoma cells. (A and B) After cells had been treated with osthole at $0,50,100,150$ and $200 \mu \mathrm{M}$ for $12 \mathrm{~h}, 24$ $\mathrm{h}$ and $48 \mathrm{~h}$ respectively, cell viability was determined by MTT assay in MG-63 and SAOS-2 cells. ** $\mathrm{p}<0.01$ vs. Control.

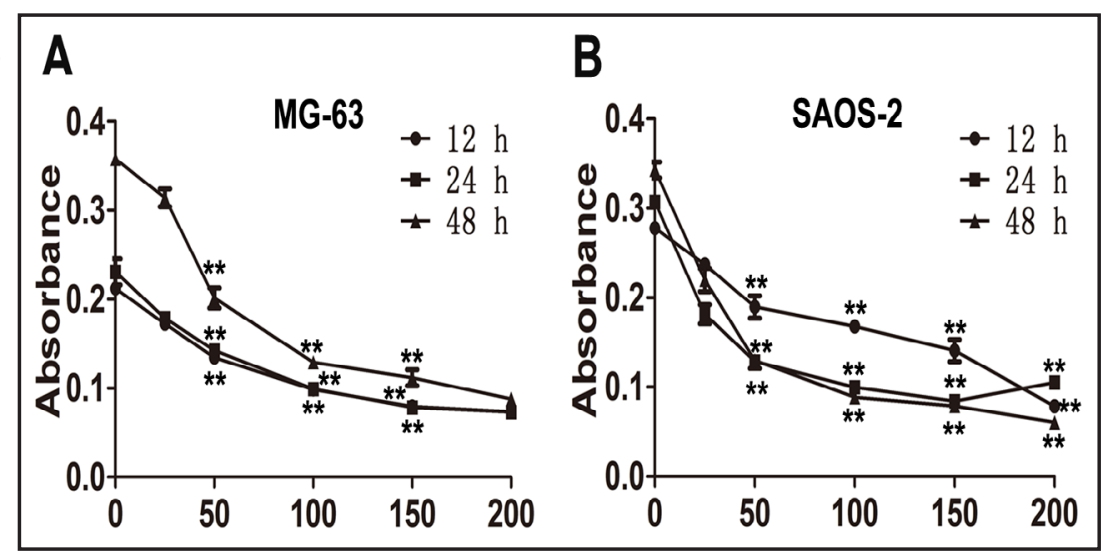




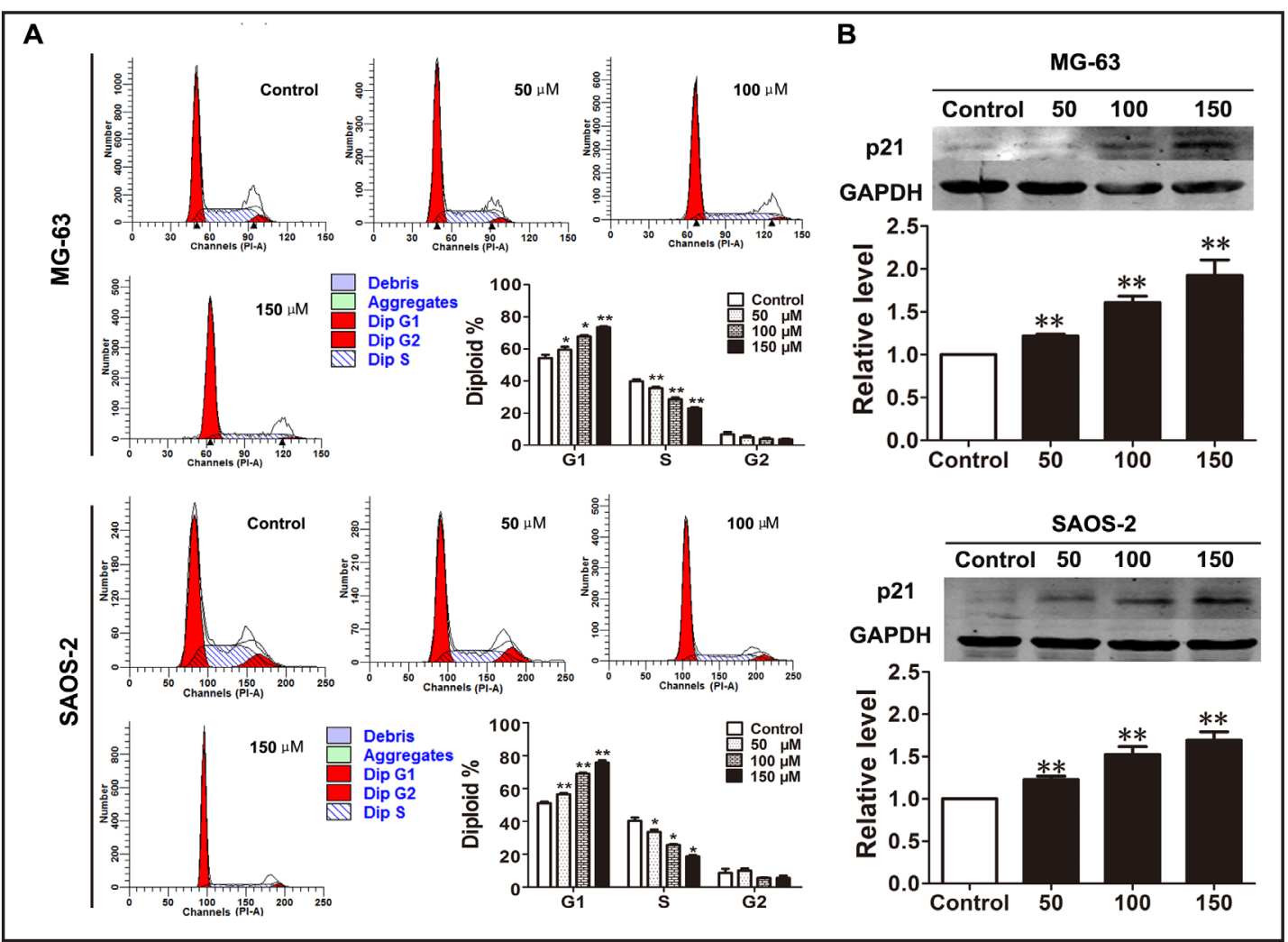

Fig. 2. Effect of osthole on cell cycle distribution of MG-63 and SAOS-2. (A) After cells had been treated with osthole at 0 (Control),50, 100 and $150 \mu \mathrm{M}$ for $24 \mathrm{~h}$, respectively, cell cycle distribution of MG-63 and SAOS-2 was detected by flow cytometry. Quantitative assay was performed and data are expressed as mean \pm SD. $\mathrm{n}=4$ for MG-63; $\mathrm{n}=3$ for SAOS- ${ }^{*} \mathrm{p}<0.05$, ${ }^{* *} \mathrm{p}<0.01$ vs. Control. (B) $\mathrm{p} 21$ protein was detected by Western blot and data were expressed as the mean \pm SEM normalized to Control. $n=5 * * p<0.01$ vs. Control.

the invasive ability, after MG-63 and SAOS-2 cells were treated with osthole, through a threedimensional matrigel-coated filter. The result revealed that ability to traverse matrigelcoated of osthole-treated MG-63 and SAOS-2 cell was decreased compared with untreated control cells (Fig. 3C). These results confirmed that osthole inhibited the migration and invasion of MG-63 and SAOS- 2 cells.

In previous study, induction of MMPs had been verified to correlate with increased metastatic potential of tumors [24, 25].Therefore the expression of MMP2 and MMP9 was detected after MG-63 and SAOS-2 cells were treated with osthole. These data indicated that the expression of MMP2 and MMP9 was decreased in osteosarcoma cells after incubating with osthole for 24h (Fig. 3D and E).

Osthole regulates the PTEN/Akt pathway to induce cell cycle arrest and reduce migration and invasion

p21, MMP2 and MMP9 have been shown to correlate with PTEN/Akt pathway. Moreover, activation of Akt is generally believed to protect cancer cells from injury and its inhibitor, PTEN, is a tumor-suppressor gene [26, 27]. To further explore the mechanism by which osthole induces the arrest of cell cycle and inhibition of migration and invasion, we examined the expression of proteins in PTEN/Akt pathway, such as PTEN and pAkt. Similar to our hypothesis, osthole up-regulated the level of PTEN (Fig. 4A) and down-regulated the expression of pAkt (Fig. 4B). These data demonstrated that osthole induces cell cycle arrest and inhibits migration and invasion of osteosarcoma mediated by PTEN/Akt pathway. 
Fig. 3. Osthole remarkably inhibits osteosarcoma cells migration and invasion. (A) Wound healing assay on the migration of MG63 and SAOS-2 cells treated with or without osthole. The percentage of the wound healing was calculated as (the width of wound at $0 \mathrm{~h}$ - the width of wound at $24 \mathrm{~h}$ )/ the width of wound at $0 \mathrm{~h}$. * $\mathrm{P}<0.05,{ }^{* *} \mathrm{P}<0.01$ compared to control. (B) Transwell migration assays of MG-63 and SAOS- 2 cells treated with or without osthole. Seven and five randomly selected fields were quantified. The values (presented as the means \pm SEM) and the statistical significance are shown. (C) Transwell invasion assays of MG-63 and SAOS-2 cells treated with or without osthole. (D) MMP2 protein was detected by Western blot and data were expressed as the mean \pm SEM normalized to Control. $\mathrm{n}=6^{* *}$ $\mathrm{p}<0.01$ vs. Control. (E) MMP9 protein was detected after osthole treatment in MG-63 and SAOS-2. $\mathrm{n}=6$ for MG$63 ; \mathrm{n}=5$ for SAOS-2 $* * \mathrm{p}<0.01$ vs. Control.

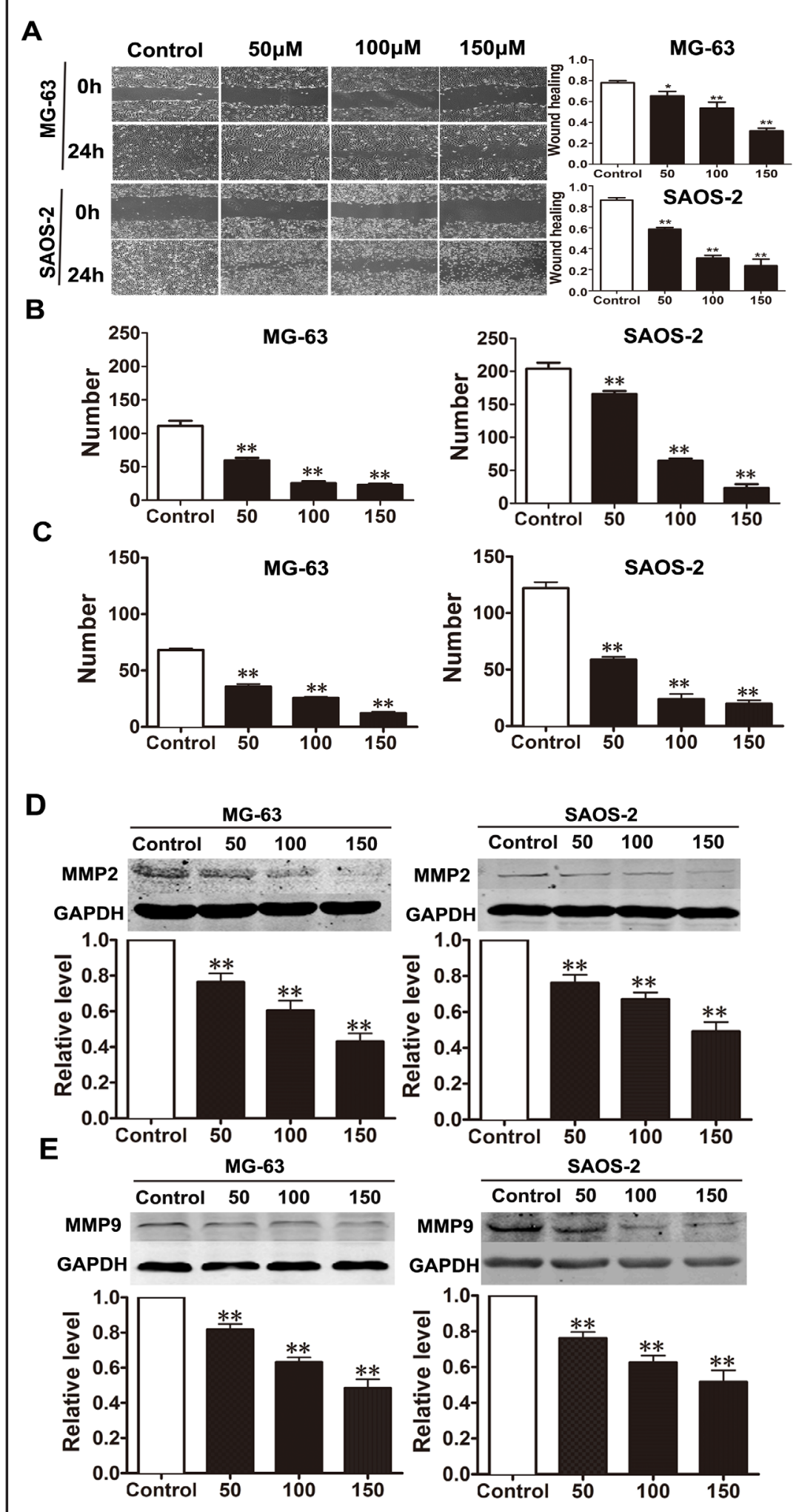

Osthole suppresses tumorigenesis of osteosarcoma cells in vivo

To explore whether osthole affects osteosarcoma in vivo, MG-63 cells were implanted subcutaneously in the flank of nude mice. At 10 days after the implantation, they were treated 
Fig. 4. Osthole regulates PTEN/Akt pathway. (A) PTEN protein was detected by Western blot and data were expressed as the mean \pm SEM normalized to Control. The levels of PTEN protein was up-regulated in MG-63 and SAOS-2 after incubating with osthole for 24h. $\mathrm{n}=6$ for MG-63; $\mathrm{n}$ $=4$ for SAOS $-2 * \mathrm{p}<0.05$, ** $\mathrm{p}<0.01$ vs. Control. (B) pAkt was down-regulated significantly in MG63 and SAOS-2 after incubating with osthole for 24 h. $\mathrm{n}=6$ for MG-63; $\mathrm{n}$ $=5$ for SAOS $-2 * \mathrm{p}<0.05$, $* * \mathrm{p}<0.01$ vs. Control.

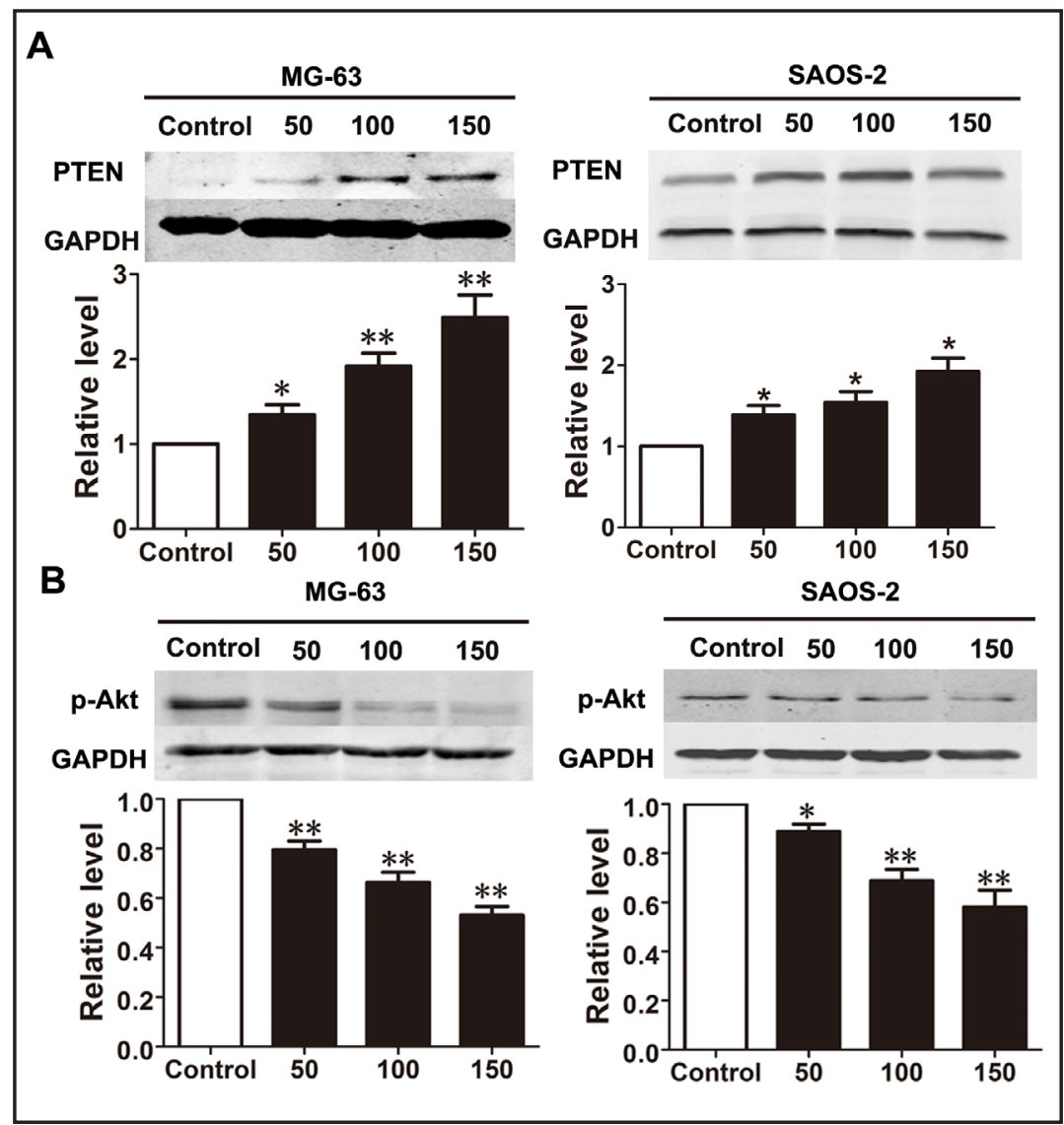

Fig. 5. Osthole ameliorates tumorigenesis of MG63 cells in vivo. (A) Photograph showing excised tumors in representative mice in each group implanted with MG-63 cells on day 30 after treatment. (B) Graph showing growth inhibition of human tumor xenografts in nude mice treated with osthole. (C) Graph illustrating the excised tumor weight on day 30 after osthole treatment.
A

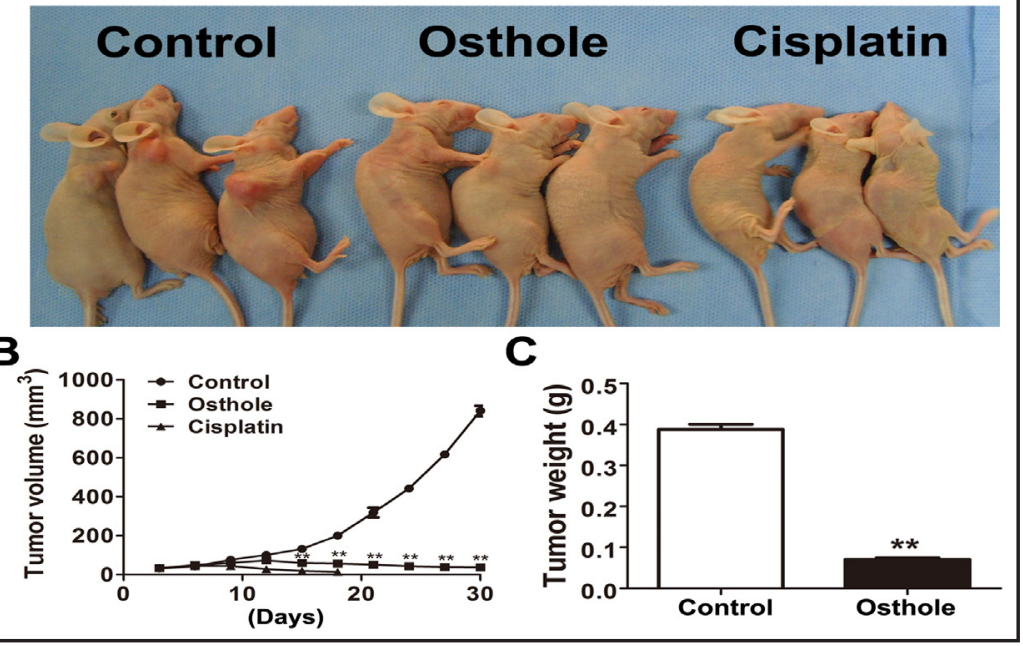

with osthole or the same volume of corn oil. Cisplatin, a platinum-based chemotherapy drug which was used to treat various types of cancers, was used as positive control. The weight of tumor was substantially lower in animals treated with osthole, and the mean tumor size at the end of the experiment was markedly smaller in these mice compared with that in the oil -injected mice (Fig. 5A). The growth curve of tumor xenografts showed that osthole markedly inhibited tumor growth (Fig. 5B). The average tumor weight in control group was nearly 5 times than that in the osthole-injected group (Fig. 5C). These results indicated that osthole could ameliorate tumor growth in vivo. 


\section{Cellular Physiology Cell Physiol Biochem 2016;38:2173-2182 and Biochemistry Published online: May 17, $2016 \quad$\begin{tabular}{l|l} 
DOI: 10.1159/000445573 2016 The Author(s). Published by S. Karger AG, Basel \\
www.karger.com/cpb
\end{tabular} \\ Wang et al.: Osthole Inhibits Osteosarcoma}

\section{Discussion}

With severe side effects and multidrug resistance, radiotherapy and chemotherapy have been used to resist cancers but are ineffective $[28,29]$. Accumulating evidence suggests that natural agents open up a new avenue for successful treatment of cancers. In previous study, the anti- cancer effect of allicin was proved. Allicin exposure induces cell apoptosis in pancreatic cancer and creates a novel approach to treatment [7]. Furthermore, the effective methods are researching and developing to improve the anti-cancer activity of natural agents, such as curcumin. Researchers try to enhance anti-lung cancer activity of curcumin via catanionic lipid nanosystems [8]. Several reports have demonstrated that osthole inhibited cell growth and proliferation by inducing apoptosis, cell cycle arrest, and inhibition of migration and invasion in various types of tumors, such as glioma, colorectal cancer, and lung cancer [14, 30 32]. Our experiment demonstrated that osthole inhibits MG-63 and SAOS- 2 cells growth by at least partially inducing cell cycle arrest and inhibition of migration and invasion, suggesting that osthole could be used for the treatment of osteosarcoma. We firstly found that the treatment of osthole induced cell cycle arrest. To illustrate the mechanism, critical regulator of cell cycle p21 was detected. It is well known that p21/WAF1/CIP1 is one of universal cyclin-CDK inhibitors that inhibit all cyclin-CDK complexes by its $\mathrm{N}$-terminal homologous sequences to induce cell cycle arrest at $G_{1}, S$, or $G_{2}$ phase [33]. As our prediction, the expression of p21 was increased obviously. Furthermore, the inhibition of migration and invasion of osteosarcoma induced by treatment with osthole was observed in our study. However, the results indicated that the inhibition of migration and invasion induced by osthole in MG-63 is stronger than that in SAOS-2 cells. The difference of sensibility to osthole may be determined by the innate characteristic of cells. MG-63 is fibroblast and SAOS-2 is epithelial cell. Though these two cell lines are originated from osteosarcoma, the innate morphology is different. Since metastatic cancer cells are always compared with the breakdown of extracellular matrix, we detected the matrix metalloproteinase MMP2 and MMP9.

PI3k/Akt pathway mediates protective effect in tumor cells. Several studies have shown that the PI3K/Akt pathway protected tissues against injury. Moreover, PTEN is generally believed to be an inhibitor of PI3k/Akt pathway and ectopic expression of PTEN suppresses tumorigenicity and cell growth [20,34-36]. In this study, we had focused on the possible mechanisms by which osthole produces anti-tumor effects in osteosarcoma. We demonstrated the important role of PTEN/Akt in mediating osthole-induced anti-tumor action. We found that osthole induced overexpression of PTEN and subsequently inactivate Akt, which likely activated p21 but inhibited MMP2/9 to trigger cell cycle arrest and regulation of migration and invasion.

In conclusion, we demonstrated that osthole induced cell cycle arrest and inhibited migration and invasion likely via regulating PTEN/Akt pathway to alter its downstream molecules expression and activities in osteosarcoma cells. Our findings uncovered the PTEN/Akt signaling pathway as a novel mechanism by which osthole produce anti-cancer effects. Thus, osthole could be potentially used in the treatment of individual patients with osteosarcoma

\section{Acknowledgements}

This work was supported by the Funds for Creative Research Groups [Grant 81421063], the Major Program [Grant 81130088] of National Natural Science Foundation of China and the Natural Science Foundation of Heilongjiang Province of China [H2015056].

\section{Disclosure Statement}

The author asserts that there is no conflict of interest related to the information included in this article. 


\section{Cellular Physiology Cell Physiol Biochem 2016;38:2173-2182 \begin{tabular}{ll|l} 
and Biochemistry & $\begin{array}{l}\text { DOI: 10.1159/000445573 } \\
\text { Published online: May 17, } 2016\end{array}$ & $\begin{array}{l}\text { (c) 2016 The Author(s). Published by S. Karger AG, Basel } \\
\text { www.karger.com/cpb }\end{array}$
\end{tabular}}

\section{References}

1 Adhikari AS, Agarwal N, Wood BM, Porretta C, Ruiz B, Pochampally RR, Iwakuma T: CD117 and Stro-1 identify osteosarcoma tumor-initiating cells associated with metastasis and drug resistance. Cancer Res 2010;70:4602-4612.

2 Yonemoto T, Hosono A, Iwata S, Kamoda H, Hagiwara Y, Fujiwara T, Kawai A, Ishii T: The prognosis of osteosarcoma occurring as second malignancy of childhood cancers may be favorable: experience of two cancer centers in Japan. Int J Clin Oncol 2015;20:613-616.

3 Hanahan D, Weinberg RA: Hallmarks of cancer: the next generation. Cell 2011;144:646-674.

4 Cmoch A, Podszywalow-Bartnicka P, Palczewska M, Piwocka K, Groves P, Pikula S: Stimulators of mineralization limit the invasive phenotype of human osteosarcoma cells by a mechanism involving impaired invadopodia formation. PLoS One DOI:10.1371/journal.pone.0109938.

5 Wu B, Cui J, Zhang C, Li Z: A polysaccharide from agaricus blazei inhibits proliferation and promotes apoptosis of osteosarcoma cells. Int J Biol Macromol 2012;50:1116-1120.

6 Liu J, Zhang L, Ren Y, Gao Y, Kang L, Qiao Q: Anticancer and immunoregulatory activity of gynostemma pentaphyllum polysaccharides in h22 tumor-bearing mice. Int J Biol Macromol 2014;69:1-4.

7 Chhabria SV, Akbarsha MA, Li AP, Kharkar PS, Desai KB: In situ allicin generation using targeted alliinase delivery for inhibition of MIA PaCa-2 cells via epigenetic changes, oxidative stress and cyclin-dependent kinase inhibitor (CDKI) expression. Apoptosis 2015;20:1388-409.

8 Li S, Fang C, Zhang J, Liu B, Wei Z, Fan X, Sui Z, Tan Q. Catanionic lipid nanosystems improve pharmacokinetics and anti-lung cancer activity of curcumin. Nanomedicine DOI:10.1016/j. nano.2016.02.007.

9 Liu Y, He J, Chen X, Li J, Shen M, Yu W, Yang Y, Xiao Z: The proapoptotic effect of formononetin in human osteosarcoma cells: involvement of inactivation of ERK and Akt pathways. Cell Physiol Biochem 2014;34:637-45.

10 Liu J, Zhang W, Zhou L, Wang X, Lian Q: Anti-inflammatory effect and mechanism of osthole in rats. Zhong Yao Cai 2005;28:1002-1006.

11 Zhang Q, Qin L, He W, Van Puyvelde L, Maes D, Adams A, Zheng H, De Kimpe N: Coumarins from Cnidium monnieri and their antiosteoporotic activity. Planta Med 2007;73:13-19.

12 Luszczki JJ, Andres-Mach M, Cisowski W, Mazol I, Glowniak K, Czuczwar SJ: Osthole suppresses seizures in the mouse maximal electroshock seizure model. Eur J Pharmacol 2009;607:107-109.

13 Huang SM, Tsai CF, Chen DR, Wang MY, Yeh WL: p53 is a key regulator for osthole-triggered cancer pathogenesis. Biomed Res Int DOI:10.1155/2014/175247.

14 Zhang L, Jiang G, Yao F, He Y, Liang G, Zhang Y, Hu B, Wu Y, Li Y, Liu H: Growth inhibition and apoptosis induced by osthole, a natural coumarin, in hepatocellular carcinoma. PLoS One DOI:10.1371/journal. pone.0037865.

15 Zhang CG, Zhu QL, Zhou Y, Liu Y, Chen WL, Yuan ZQ, Yang SD, Zhou XF, Zhu AJ, Zhang XN, Jin Y: N-Succinylchitosan nanoparticles coupled with low-density lipoprotein for targeted osthole-loaded delivery to lowdensity lipoprotein receptor-rich tumors. Int J Nanomedicine 2014;9:2919-2932.

16 Chen TJ, Zhou YF, Ning JJ, Yang T, Ren H, Li Y, Zhang S, Chen MW: NBM-T-BMX-OS01, an Osthole Derivative, Sensitizes Human Lung Cancer A549 Cells to Cisplatin through AMPK-Dependent Inhibition of ERK and Akt Pathway. Cell Physiol Biochem 2015;36:893-906.

17 Chalhoub N, Baker SJ: PTEN and the PI3-kinase pathway in cancer. Annu Rev Pathol 2009;4:127-150.

18 Song MS, Salmena L, Pandolfi PP: The functions and regulation of the PTEN tumour suppressor. Nat Rev Mol Cell Biol 2012;13:283-296.

19 Salmena L, Carracedo A, Pandolfi PP: Tenets of PTEN tumor suppression. Cell 2008;133:403-414.

20 Castaneda CA, Cortes-Funes H, Gomez HL, Ciruelos EM: The phosphatidyl inositol 3-kinase/AKT signaling pathway in breast cancer. Cancer Metastasis Rev 2010;29:751-759.

21 Srivastava RK, Chen Q, Siddiqui I, Sarva K, Shankar S: Linkage of curcumin-induced cell cycle arrest and apoptosis by cyclin-dependent kinase inhibitor p21(/WAF1/CIP1). Cell Cycle 2007;6:2953-2961.

22 Normanno N1, De Luca A, Bianco C, Strizzi L, Mancino M, Maiello MR, Carotenuto A, De Feo G, Caponigro F, Salomon DS: Epidermal growth factor receptor (EGFR) signaling in cancer. Gene 2006;366:2-16. 


\section{Cellular Physiology Cell Physiol Biochem 2016;38:2173-2182 \begin{tabular}{l|l} 
DOI: 10.1159/000445573 & $\begin{array}{l}\text { O 2016 The Author(s). Published by S. Karger AG, Basel } \\
\text { www.karger.com/cpb }\end{array}$
\end{tabular} \\ Wang et al.: Osthole Inhibits Osteosarcoma}

23 Shan H, Zhang Y, Lu Y, Zhang Y, Pan Z, Cai B, Wang N, Li X, Feng T, Hong Y, Yang B: Downregulation of miR-133 and miR-590 contributes to nicotine-induced atrial remodelling in canines. Cardiovasc Res 2009;83:465-472.

24 Meng XN, Jin Y, Yu Y, Bai J, Liu GY, Zhu J, Zhao YZ, Wang Z, Chen F, Lee KY, Fu SB: Characterisation of fibronectin-mediated FAK signalling pathways in lung cancer cell migration and invasion. Br J Cancer 2009;101:327-334.

25 Jacob A, Jing J, Lee J, Schedin P, Gilbert SM, Peden AA, Junutula JR, Prekeris R: Rab40b regulates trafficking of MMP2 and MMP9 during invadopodia formation and invasion of breast cancer cells. J Cell Sci 2013;126:4647-4658.

26 Meng F, Henson R, Wehbe-Janek H, Ghoshal K, Jacob ST, Patel T: MicroRNA-21 regulates expression of the PTEN tumor suppressor gene in human hepatocellular cancer. Gastroenterology 2007;133:647-658.

27 Hsu YH, Chang CC, Yang NJ, Lee YH, Juan SH: RhoA-mediated inhibition of vascular endothelial cell mobility: positive feedback through reduced cytosolic p21 and p27. J Cell Physiol 2014;229:1455-1465.

28 Szakacs G, Paterson JK, Ludwig JA, Booth-Genthe C, Gottesman MM: Targeting multidrug resistance in cancer. Nat Rev Drug Discov 2006;5:219-234.

29 Tan W, Lu J, Huang M, Li Y, Chen M, Wu G, Gong J, Zhong Z, Xu Z, Dang Y, Guo J, Chen X, Wang Y: Anti-cancer natural products isolated from chinese medicinal herbs. Chin Med 2011;6:27.

30 Ding D, Wei S, Song Y, Li L, Du G, Zhan H, Cao Y: Osthole exhibits anti-cancer property in rat glioma cells through inhibiting PI3K/Akt and MAPK signaling pathways. Cell Physiol Biochem 2013;32:1751-1760.

31 Liu LY, Huang WJ, Lin RJ, Lin SY, Liang YC: N-Hydroxycinnamide derivatives of osthole presenting genotoxicity and cytotoxicity against human colon adenocarcinoma cells in vitro and in vivo. Chem Res Toxicol 2013;26:1683-1691.

32 Yang HY, Hsu YF, Chiu PT, Ho SJ, Wang CH, Chi CC, Huang YH, Lee CF, Li YS, Ou G, Hsu MJ: Anti-cancer activity of an osthole derivative, NBM-T-BMX-OS01: targeting vascular endothelial growth factor receptor signaling and angiogenesis. PLoS One DOI:10.1371/journal.pone.0081592.

33 Abbas T, Dutta A: p21 in cancer: intricate networks and multiple activities. Nat Rev Cancer 2009;9:400414.

34 Li J, Simpson L, Takahashi M, Miliaresis C, Myers MP, Tonks N, Parsons R: The PTEN/MMAC1 tumor suppressor induces cell death that is rescued by the AKT/protein kinase B oncogene. Cancer Res 1998;58:5667-5672.

35 Minaguchi T1, Mori T, Kanamori Y, Matsushima M, Yoshikawa H, Taketani Y, Nakamura Y: Growth suppression of human ovarian cancer cells by adenovirus-mediated transfer of the PTEN gene. Cancer Res 1999;59:6063-6067.

36 Yue S, Li J, Lee SY, Lee HJ, Shao T, Song B, Cheng L, Masterson TA, Liu X, Ratliff TL, Cheng JX: Cholesteryl ester accumulation induced by PTEN loss and PI3K/AKT activation underlies human prostate cancer aggressiveness. Cell Metab 2014;19:393-406. 